\title{
The flora of Azerbaijan for the world horticulture
}

\author{
Valida M. Ali-zade ${ }^{1}$ \\ Institute of Botany, Azerbaijan National Academy of Sciences, \\ Badamdar 40, Baku, AZ1004, Azerbaijan \\ Tatyana Shulkina ${ }^{2}$ \\ The Field Museum of Natural History, 1400 S. Lake Shore Drive, \\ Chicago, IL 60605 USA
}

\begin{abstract}
The Caucasus is the first and only one area within the former Soviet Union identified as a "biodiversity hotspots" among 25 other areas worldwide. Recent publication of the new geographical map confirmed the Caucasus as a part of Europe. Among southern Caucasus countries Azerbaijan is country with the most botanical riches possesing the extremely diverse native flora - a wonderful source for horticulture needs that is provided by each of types of vegetation with valuable ornamental plants. The list of important ornamental plants that there are great possibilities for introduction activity in different environmental conditions and short analysis their origin and distribution in Azerbaijan have been shown in the article.Trees, shrubs and herbaceous species, growing in the regions of Azerbaijan, many of which are promising for gardering are unknown or poorly known in horticulture. It was emphasized the Talysh herbaceous endemics are of considerable horticulture interest because of highly attractive nature. Some species are extremely rare in nature and in cultivation. It is noted, that the large collections of the ornamental plant species are under investigation in the Central Botanical Garden and arboretum in Baku. Some plants from this collection are promising ornamentals and might be successfully grown in the gardens. Azerbaijan is country where many species are dissappeared because of ongoing perils such as habitat loss, over collection, new roads and industrial developments, etc. There are powerful reasons to protect this great diversity of species from increasing pressures, given its exceptional importance for endangered wildlife.
\end{abstract}

Key Words: ornamental plants, wild species, origin, distribution, introduction, Caucasus.

\section{Accepted for publication: 5 December 2018}

1,2E-mail: vm alizade@yahoo.com; tshulkina@fieldmuseum.org
There is a common opinion that the Caucasus is one of the most beautiful regions in the World. Not only local patriots love the place but also visitors admire the beauty of the region. Wonderful mountains peaks covered with snow, subalpine and alpine meadows with unusual flowers and mountain rivers with crystal water - all are very impressive. The nature of the Caucasus is extraordinary rich and there is a historical explanation of this fact. The matter is the Caucasus is one of three regions in the Northern Hemisphere that survived since the Ice Ages of the Pleistocene. They are: 1) the Hengduan and Qingling mountains in south-central China, 2) the southeastern United States, and 3) the western Eurasia (Mediterranean), including the Caucasus [Raven, 2013, Borsch, 2014].That is why the flora of the Caucasus is very rich - it includes 6,300 species of vascular plants with a great deal of endemics - 2,790 spp. [Solomon, Shulkina, Schatz, 2013]. It means that more than two thousand and a half species occur only in the Caucasus and nowhere else. Among 25 areas worldwide only the Caucasus within the former Soviet Union is area identified as a "biodiversity hotspots".

The nature of the Caucasus has been studied in details, but actually each region has been treated separately not as a part of the entire region. The reason of such an approach was political isolation of the large part of the Caucasus that used to belong to the Soviet Union Empire. Recently the Komarov Botanical Institute has started publication Caucasian Flora Conspectus [2003] that covers three southern Caucasian countries (Armenia, Azerbaijan, Georgia) and the north part of the region belonging to Russia. Absence of the general analysis was the reason why the Caucasus was not presented in the Flora Europaea, and in the Med-Checklist, which inventoried the vascular plants of the Mediterranean countries. Some years ago geographical position of the Caucasus was a subject for discussion - whether the Caucasus is a part of Europe or it should be included in Asia. Recent publication of the new geographical map confirmed the Caucasus as a part of Europe [Bohn et al. 2003]. The new edition of the Flora Europaea (if any) should include the Caucasian plants. The Caucasian botanists have to become active members of the World botanical community. 
It is especially true for Azerbaijan largely because it is the botanically rich country within the Caucasus [Korjagin, 1950-1961]. The flora of the country is of great interest for any botanists, including ethnobotanists and gardeners. The Caucasian flora is a wonderful source of new food and medicinal plants and new ornamentals. As it is known the Caucasus was one of the major centers of economic plants [Vavilov, 1958-1964]. Many important food plants came from the Caucasus such as cereal species, rye, pea, Colchis flax, most of the pear species, oriental apple, medlar, cornelian cherry, cherry, and plump. Some of the ancestral species and their relatives still grow in the wild and they are of great interest for practical agricultural specialists for future hybridization work. The territory of the Caucasus is the homeland for many well-known ornamentals. The process of introduction of new plants into world horticulture was very slow during the last 80 years due to the political isolation. Right now these countries are open for collaboration and new opportunities exist.

The flora of Azerbaijan includes 4500 species of vascular plants, where 950 are the Caucasian and 200 are national endemics [Ali-zade et al. 2013]. Forests occupy $11.4 \%$ of the territory, predominately in the Greater and the Lesser Caucasus and also in the Talysh Regionit is the southeastern part of the country. Presence of the forest tracts differ the Caucasus from East Mediterranean Region, where native forests almost disappeared. Plains, steppes and deserts occupy $31.8 \%$ of the territory, and more than a half of the country is mountains and highlands. Azerbaijan demonstrates an extremely diverse native flora - a wonderful source for horticultural needs. Each of these types of vegetation can provide horticulture with valuable ornamental plants. A number of Azerbaijan species are already among wellknown garden plants. Silk tree, Albizia julibrissin Durazz., might be a good example. This wonderful graceful tree can be seen in many gardens in Europe and in the United States. Successful in gardens are Gladiolus atroviolaceus Boiss. and Primula juliae Kusn. - also native to Azerbaijan. However, many species that are promising for gardening are unknown or poorly known in horticulture. Therefore, the flora should be carefully studied and ornamentals can be found in different type of vegetation.

Gardeners usually pay much attention to woody plants. Forests in Azerbaijan are rich. According to S. Sokolov studies [1965] the entire number of genera with woody and semi-wooden plants in the Caucasus is 176 and the large number of species grow in the South- western and Southeastern regions, namely in Azerbaijan. Many of these species are common with Mediterranean Region and are well known in horticulture. Thus, beech, Fagus orientalis Lipsky is the most noble of trees, can be seen all over in the gardens in different continents. In the Caucasus this species occupies $25 \%$ of all forest territory [Grossheim, 1952]. Common hornbeam, Carpinus betulus L., and some oaks such as chestnut-leaved oaks Quercus castaneifolia C.A. Mey. and Q. macranthera Fisch. \& C.A. Mey.ex Hohen. are well known as well. However, Azerbaijan forests have a number of unique characters and species unknown for horticulture. Thus, in southeastern region of the country the major tree in the forest is Persian iron wood, Parrotia persica (DC.) C.A. Mey. It is a member of monotypic genus of the Hamamelidaceae family, endemic to Talysh and northern Iran. The Talysh forest has been called "Hyrcanian" by botanists as an indication of their age [Grossheim, 1960]. The Hyrcanian Sea filled an ancient large basin and was the predecessor of today's Caspian Sea. However, the Talysh mountains were never submerged, and this is why the endemic $P$. persica has persisted here since the early Tertiary period. This tree forms here nearly pure stand. It is actually almost unknown in gardens and even the wonderful Manual of Trees \& Shrubs, completed by J. Hillier [1981] and published in the Great Britain presents wrong description of this species. In nature it is a deciduous tree up to $25 \mathrm{~m}$ tall of wide spreading habit, not "a large shrub or small tree" as it is described in the Manual. The reason of this mistake is probably in that it is a very slow growing plant that creates a wrong impression of its size. This tree is not only a slow growing but also an extremely long living plant. There are many trees in Talysh forest which are hundreds of years old. Large dark green leathery leaves turn crimson with lilac tint in autumn. Leaves do not fall down until mid of winter and beautify the forest with its color for a long autumn and a part of winter. Plant can be used as a solitary tree and for hedging purposes.

Talysh being a unique floristic region [Gadjiev et al, 1979] has a floral composition that differs from that in neighboring regions in Azerbaijan and Iran especially in a number of relicts of the Tertiary period. It is not only P. persica but also silk tree (Persian pink siris), Albizia julibrissin Durazz., Zelkova hyrcana Grossh. \& Jarm., that in Western publications sometimes included in Zelkova carpiniifolia (Pall.) K. Koch - a large tree that is a very long living plant deserving much attention. Some other species should be mentioned here such as 
Oriental persium, Diospurus lotus L., Hyrcan butcher's broom, Ruscus hyrcanus Woronow, Alexander laurel, Danae racemosa (L.) Moench, Hyrcan box-tree, Buxus hyrcana Pojark. The only representative from the genus Gleditsia L. within the flora of the former Soviet Union grows in Lankaran region in lowland and in hills. Gleditsia caspica Desf. is a middle size tree with trunks formidably armed with numerous spines. Leaflets larger than in most species. It is a very good plant for hedging purposes. In mountain forest one can see a nice maple - Acer hyrcanum Fisch. \& C.A. Mey. Hyrcan maple is a tree up to $15 \mathrm{~m}$ in height with five-lobed leaves. It is a very slow growing plant, recorded in cultivation only in warm regions [Safarov, 2009]. Most of mentioned species are included in the Red Book of Azerbaijan and occur in the reservation. The Hirkan State Reserve (2906 hectares) was established in Talysh in 1936 for the conservation of relict and endemic species of the tertiary period that were found in this region. Later, in 2004, the State Reserve was transformed into the Hirkan National Park covers an area of 21.435 hectares with 1200 plant species being endemic and need conservation.

There are a number of oak species in the Azerbaijan forests that are unknown or poorly known such as $Q$. iberica Steven, Q. boissieri Reut. and $Q$. pubescens Willd. The first species $-Q$. iberica is a large tree (20$40 \mathrm{~m}$ ) with rather large leaves (up to $20 \mathrm{~cm}$ long and $10 \mathrm{~cm}$ wide). It is distinguished by being very dry resistant plant. $Q$. boissieri - usually shrubby, occasionally a small tree is also very good for dry region. $Q$. pubscens can be used for topiary forms. Betula radeana Trautv. is a small or medium size tree and can be used for hedges. Among other woody plants that merit horticultural attention might be mentioned: Pinus kochiana Klotzsch ex K. Koch - a small tree or shrub, Juniperus foetidissima Willd. - a small tree; both species are cold and dry resistant. The genus Pyrus L. (pears) has many representatives in the Caucasus, especially in the southern regions (Musayev et al. 2009). These species are of interest not only for their fruit but also for beautiful shape and leaves. P. boissieriana Buhse - a tree or shrub up to $5 \mathrm{~m}$ tall; $P$. grossheimii Fed. - a tall tree with oval shape; $P$. hyrcana Fed. - a tall tree, with no spiny branches; P. vsevolodii Heideman - a small tree; P. eldarica Grossh. - a shrub $1 \mathrm{~m}$ tall; P. salicifolia Pall. - a tree 8-10 m tall, leaves narrow silvery-grey; $P$. medvedevii Rubtz. - a tree 10-12 m with long branches. All mentioned plants are quite tolerant both for drought and cold. Some other wooden plants are very promising for world horticulture, such as Acer velutinum Boiss. - a tall tree with very large leaves; $A$. trautvetteri Medw. - a medium size tree with large five lobed leaves (14-16 $\mathrm{cm})$. Also in southeastern region one can see Fraxinus coriariifolia Scheele, Corylus colurna L. Cydonia oblonga L., Pistacia mutica Fisch. \& C.A. Mey.-unknown and well known plants. Unknown for horticulture are Populus euphratica Olivier - a medium size tree with rounded slightly toothed leaves; and Populus hyrcana Grossh. - also a medium size tree with rhomb-shaped leaves, pale green, almost white due to woolly hair. Both species are very spectacular, heat and dry resistance; recommended for special environmental conditions [Shulkina, 2004]. A number of native trees are under investigation in the Azerbaijan Botanical Gardens and Arboreta.

Shrubs in the Caucasus are represented in a number of genera such as Berberis L., Hymenocrater Fisch. \& C.A. Mey., Euonymus L., Lonicera L., Punica L., Rosa L., and others. Within the genus Berberis L. two species should be mentioned: B. densiflora Boiss. \& Buhse and B. iberica Steven, \& Fisch. ex DC. - both shrubs are of medium size, with leathery leaves and many flowered (20) racemes; bright red fruits in autumn. They are dry resistant. However, Berberis species are not very much desirable for American gardens due to many reasons (diseases etc.). Semi-shrub Hymenocrater bituminosus Fisch. \& C.A. Mey. (Lamiaceae Lindl.) occurs in steppe in hills. It has erect stem up to $1 \mathrm{~m}$ tall, and yellowviolet numerous flowers in spike- like inflorescence (verticillaster). Extremely dry resistant. A well-known plant for hedge everywhere is Euonymus europaeus L. - "spindle". However, in the Caucasus in Azerbaijan occurs Euonymus velutina Fisch. \& C.A. Mey. that is one of the most beautiful species in the genus. Akin to E. europaeus it differs in its wider and numerous inflorescences, and numerous bright colored fruits. Caucasian honeysuckles, Lonicera caprifolium L. grows here in nature. Honeysuckles are long cultivated climber plants, but $L$. iberica Bieb. is very rare in gardens in spite of the fact that it is very beautiful having orbicular leaves and bright red berries that make this a distinctive species. The genus Rosa represents in Azerbaijan by the species that are of wide distribution within the Caucasus, such as Rosa boissieri Crep., R. iberica Steven ex Bieb., $R$. pulverulenta Bieb.; and also by the species restricted to a small region: $R$. komarovii Sosn., $R$. karjaginii Sosn., $R$. zangezura P. Jarosch. Azerbaijan botanists have been studying garden roses for many years since 70 years of the last century. The large collections of the garden roses are located in the Central 
Botanical Garden of the National Academy of Sciences of Azerbaijan in Baku. Complex of biological and agronomical traits allowed identifying 184 rose varieties recommended for use in landscaping and gardening and the city beautification in Absheron and Azerbaijan cities [Iskanderov et al., 2017]. Experience in breeding roses in the Central Botanical Garden has indicated that the research of intervarietal and distance hybridization during 2009-2014 years were received more than 800 hybrid seedlings.

Evergreen plants are very desirable for horticulture. Some of them are found in this particular flora: Ilex hyrcana Pojark. with small leaves; Hedera pastuchowii Woronow climbing vine with large leaves; and Buxus hyrcana Pojark. a very dry resistant plant. In subalpine zones one can see Rhododendron caucasicum Pall.- it is a parent of old hardy hybrids widely used in horticulture, while the other Rhododendron - R. luteum Sweet is deciduous species, well-known fragrant azalea. Strong fragrance is also recorded for Philadelphus caucasicus Koehne - shrub $3 \mathrm{~m}$ high, with large flowers produced in clusters of 7-11. Species is almost unknown in horticulture. This short list includes only a small part of Azerbaijan woody plants; however it shows that there are great possibilities for horticulture to choose new ornamental species for different environmental conditions. A number of trees and shrubs have been studied in the Botanical Garden and Arboreta. The introduction activity might be illustrated by numbers. The first number -223 shows how many woody plants were grown in the park and gardens in the capital city - in Baku in the middle of the last century. This set consists of native plants and species from all over the World. There were 40 species from Asia (mostly from Japan and China) and 23 species from North America [Agamirov 1977]. Right now the number of introduced species originated from Asia is 187 and the number North American species was doubled.

Herbaceous plants of the Caucasus are enormously diverse and many genera well-known in horticulture have representatives in the flora of Azerbaijan. Among monocots one of the richest genus is Iris. Name just a few: I. caucasica Hoffm., I. schischkinii Grossh., I. pseudocaucasica Grossh., I. atropatana Grossh., I. reticulata Bieb., I. hyrcana Woronow ex Grossh., I. demetri Achv. \& Mirzoeva, I. musulmanica Fomin, I. cartaliniae Fomin, I. paradoxa Steven, I. alexeenkoi Grossh., I. imbricata Lindl. Not many species of this list were taken in horticulture; it will be done in future. The genus Crocus L. belongs to the same family Iridaceae
Juss. Endemics of Talysh region - Crocus polyanthus Grossh., and also C. caspius Fish. \& C.A. Mey., and $C$. adamii J. Gay are of special interest. The family Liliaceae Juss. has wonderful representatives in Azerbaijan. First of all it is a beautiful lily - Lilium ledebourii (Baker) Boiss. occurs in Talysh and north Iran. It has snow white flowers with bright scarlet anthers. It is very strange that it has not been so far introduced into horticulture and involved into hybridization. The other species - L. monadelphum Bieb. is well-known. Genus Fritillaria L. has also unusual species, poorly known in horticulture - it is a species described by A. Grossheim from Talysh region (Leric and Yardymlinsky districts) - F. grandiflora Grossh. with flowers large, solitary, brown-purple, checkered. Other species $F$. caucasica Adams and F. armena Boiss. also deserve to be introduced to horticulture. The genus Tulipa L. is not very numerous in Azerbaijan, however, these species are very beautiful. Thus T. eichleri Regel (section Leiostemones) is a classical tulip with bright red flowers - it is the best in Azerbaijan. Others are nice as well: T. florenskyi Woronow, T. julia K. Koch. The flowers of these three species are beautiful but $T$. eichleri is the best. Many other monocot species deserve special attention [Ibadli, 2002]. Among them local endemics (Ornithogalum hyrcanum Grossh.-Talysh) and species that occur widely in the Caucasus (Scilla caucasica Miscz., Muscari neglectum Guss., Sternbergia fischeriana (Herb.) M. Roem., Allium paradoxum (Bieb.) G.Don fil.) and many others.

Ornamental dicots are very numerous within the flora of Azerbaijan. Unknown and poorly known species can be recorded even within famous garden genera such as Campanula L., Geranium L., Paeonia L., Primula L., Saxifraga L. Let us take Paeonia- the famous and favorite garden plant. As is known that almost all varieties of garden Paeonia originated from one species - Paeonia lactiflora Pall. that occurs in the Far East (Russia, Manchuria, Korea, China, Tibet). Just a few cultivars originated from European species $P$. officinalis L. Selection in Paeony needs fresh blood and the Caucasus can help in it. In Talysh forests one can see a wonderful plant - Paeonia tomentosa (Lomak.) N. Busch having unusual light yellow flowers with dark red stamen stalk. This color is new for the genus therefore it will be a horticultural discovery. Another yellow-flowered species $-P$. mlokosewitschii Lomak. occurring in northwestern region of Azerbaijan, in Zagatala reserve was more successful in introduction and now it presents in some botanical gardens in Europe and 
USA. Both species are gems of the genus. A wonderful plant from rocky places in Southern Caucasus is stonecress - Aethionema edentulum N. Busch- it is an evergreen subshrub $(20-30 \mathrm{~cm})$ with blue-green foliage and with numerous pink flowers. A flowering period lasts for two months that makes this species a very valuble for horticulture. Some new species of Primula might be taken to horticulture such as P. heterochroma Stapf. Bellflowers are mostly known from alpine zone (Campanula aucheri A.DC.), some are recorded from steppe and hills (C. stevenii Bieb.).

Many Azerbaijan botanists paid attention to ornamental promising plants. Some of them have named the most valuable ones. Thus H. Safarov [2009] offered to taste in cultivation: Allium lenkaranicum Miscz. ex Grossh., Muscari grosshemii Schchian, Epimedium pinnatum Fisch., Papaver chelidoniifolium Boiss. \& Buchse, Alchemilla hyrcana (Bus.) Juz., Alcea hyrcana (Grossh.) Grossh., Primula heterochroma Stapf, Scrophularia clausii Boiss. \& Buhse.

The family Asteraceae is one of the dominated families within the Caucasian flora. The representatives from the family were the objects of special studies (Aghayeva et al., 2018). Plants were collected in Quba and Qusar. Collection covers 28 genera (belonging to 11 tribes) and 49 species. New localities were recorded for Callicephalus nitens (Bieb.) C.A. Mey., Centaurea cheiranthifolia Willd., Leontodon danubialis Jacq. Life forms and rhythm of vegetation were studied. It was shown that life form and longevity of life depend on environmental conditions of the place of origin. One and the same plant species might grow as annual, biennial, or perennial. Thus, Erigeron acris L., Lactuca serriola L., and Senecio vernalis Walds. \& Kit. may grow as both annual or biennial, ( $S$. vernalis sometimes as perennial), while Carduus nutans L. is mainly perennial. Some plants from this collection are promising ornamentals and might be successfully grown in the gardens.

This short analysis has a goal to show that the flora of Azerbaijan is a wonderful source for ornamental plants. New evergreen and deciduous woody plants might be added to horticulture. New perennials will beautify the current set of herbaceous plants. What is of importance is the fact that many of them are dry resistant. The territory of Azerbaijan is situated from climate zone 5 (high mountains area) until zone 7 in Lenkaran region. Therefore most species will be successful in Midwest and in the West Coast regions in the USA.

Next climate change and increasing anthropogenic impacts will interact with various environmental factors. Caucasus ecoregion, including Azerbaijan is also the "hotspot" - area to a great diversity of species and a globally significant ecosystems, where many species are dissappeared [Red Book of Azerbaijan, 2013].

The Caucasus is the first and only one area within the former Soviet Union identified as a "biodiversity hotspots" among 25 other areas worldwide. Recent publication of the new geographical map confirmed the Caucasus as a part of Europe. Among southern Caucasus countries Azerbaijan is a country with the most botanical riches possesing the extremely diverse native flora - a wonderful source for horticulture needs that is provided by each of types of vegetation with valuable ornamental plants. The list of important ornamental plants that there are great possibilities for introduction activity in different environmental conditions and short analysis their origin and distribution in Azerbaijan have been shown in the article.Trees, shrubs and herbaceous species, growing in the regions of Azerbaijan, many of which are promising for gardering are unknown or poorly known in horticulture. It was emphasized the Talysh herbaceous endemics are of considerable horticulture interest because of highly attractive nature. Some species are extremely rare in nature and in cultivation. It is noted, that the large collections of the ornamental plant species are under investigation in the Central Botanical Garden and arboretum in Baku. Some plants from this collection are promising ornamentals and might be successfully grown in the gardens. Azerbaijan is country where many species are dissappeared because of ongoing perils such as habitat loss, over collection, new roads and industrial developments, etc. There are powerful reasons to protect this great diversity of species from increasing pressures, given its exceptional importance for endangered wildlife.

\section{REFERENCES}

Agamirov, U.M, (1977) Novie drevesniye porodi dlya ozeleneniya Apsherona. Elm, Baku. 112 p. (In Russian)

Aghayeva P.N., Garakhani P.X., Huseynova A., Alizade V.M. (2018) Wild ornamental plants of the family Asteraceae from the northeastern part of Azerbaijan. Чорноморський ботанічний журнал. 14(3): 204-212.

Ali-zade V.M., Hajiev V.C., Kerimov V., Musaev S., Abdiyeva R. (2013) Azerbaijan. P. 73-108 In: J. Solomon, T. Shulkina, J. Schatz (editors), Red List of the Endemic Plants of the Caucasus. MBG Press, 
St. Louis, USA

Bohn U., Neuhausl R. (2003) Map of the Natural Vegetation in Europe. Teil 3, Karten. Landwirtschauftsverlag, Munster.

Borsch T. (2014) Caucasus. Plant diversity between the Black and Caspian Seas. Eds. G. Parolly, K. Grotz, W. Lack. 232 p.

Flora Azerbaidjana (1950-1961) Ed.: I.I. Kojagin.Baku: AN Azerb. SSR, 1-8. (In Russian)

Gadjiyev V., Guliyeva Kh., Vagabov Z. (1979) Flora i rastitelnost visokoqoriy Talysha. Baku: Elm, 159 p. (In Russian)

Grossheim A.A. (1952) Flora of the Caucasus, 5. İzdadelstvo Akademiya Nauk, Moskva. 453 pp. (In Russian)

Grossheim A.A. (1948) V qorax Talysha. Izdadelstvo Akademiya Nauk SSSR, Moskva, 122 p. (In Russian)

Hillier J., R. (1981) Manual of Trees and Shrubs. Redwood Burn Ltd, Trowbridge, Wilt, UK.

Ibadli O. (2002) Qafqazın geofitləri. Baku: Elm, 271 p.

Iskenderov A.T., Gafarova O.O., Farzaliyev V.S. (2017) Rezultati i perspektivi seleksii sadovix roz v Sentralnom Botanicheskom Sadu NAN Azerbaidjana. Bulleten Qlavniqo Botanicheskoqo Sada, RAN 3: 194198. (In Russian)

Konspekt Flori Kavkaza (2003-2006) Ed. A.L. Takhtajan, 1, 2, 3. St. Petersburg University Press, St. Petersburg. (In Russian)

Musaev S., Farzaliev V., Abdiyeva R., Ali-zade V. (2009) Obzor i otsenka statusa potetsialno ischezayushikh vidov Pyrus L. v Azerbaidjane. Trudi Instituta Botaniki Natsionalnoy Akademii Nauk Azerbaidjana. Baku: Elm, 29: 9-15. (In Russian)

Raven P.H. (2013) Foreword. In: Solomon J., Shulkina T., Schatz G. Red list of the Endemic Plants of the Caucasus. MBG, St. Louis, USA, 451 pp.

Red book of Azerbaijan. (2013) Rare and endangered plant and fungi species. Second edition., Baku, 676 pp.

Rozy v Tsentralnom Botanicheskom Sady Sibirskogo Otdelenia RAN, Bull. GBS, 3: 194-198. (In Russian)

Safarov H. (2009) Rare and Endangered Plant Species in Hircan National Park and its Environs. In: "Status and protection of globally threatened species in the Caucasus" p.193-198. Eds. N. Zazanashvili and D. Mallon, Tbilisi 205 pp.

Shulkina T. (2004) Ornamental Plants from Russia and adjacent states of the former Soviet Union. Rostok, St. Petersburg. 316 pp.
Sokolov S.Y., Sviazeva O. A. (1965) Khorologia drevesnykh rastenii SSSR. Moskwa: Nauka, 39s. (In Russian)

Solomn J., Shulkina T., Schatz G. (2013) Red List of the Endemic Plants of the Caucasus. Armenia, Azerbaijan, Georgia, Iran, Russia, and Turkey. MBG, St. Louis, USA

Vavilov N.I. (1958-1964) Izbrannye sochinenia. Moscow, I-IV: 1200s. (In Russian)

\section{Azərbaycan florası dünya bağçılığında}

Validə M. Đli-zadə

AMEA Botanika Institutu, Badamdar şossesi 40, Bakl, AZ1004, Azarbaycan

Tatyana Şulkina

Tabii Tarixi Çöl Muzeyi, 1400 S. Lake Shore Drive, Çikaqo, Illinoys 60605, $A B S ̧$

Keçmiş Sovet İttifaqunda Qafqaz ilk və yeganə ərazidir ki, dünyada "biomüxtəliflik üzrə qaynar nöqtə"lər kimi tanınan 25 ərazidion biridir. Yeni coğrafi xəritənin son nəşrində Qafqaz Avropanın bir hissəsi kimi təsdiq edilib. Cənubi Qafqaz ölkələri arasında Azərbaycan olduqca rəngarəng təbii floraya və bitkiliyə malik - bağçılıq ehtiyacları üçün qiymətli hər tip dekorativ bitkilərin füsunkar mənbəyini təmin edən ölkədir. Məqalədə müxtəlif ətraf mühit şəraitinə introduksiya üçün böyük imkanları olan mühüm dekorativ bitkilərin siyahısı, Azərbaycanda onların mənşəyi və yayılmasının qısa təhlili verilmişdir. Azərbaycanın müxtəlif bölgələrində bitən və əksəriyyəti bağç1lıq üçün münasib olan ağaclar, kollar və otlar bağçılıq üçün ətraflı araşdırılmayıb və ya az öyrənilib. Qeyd edilib ki, Talışın ot endemləri yüksək cəlbedici xüsusiyyətlərinə görə bağçılıqda böyük maraq doğurur. Bəzi növlər təbiətdə və əkinlərdə olduqca nadir halda rast gəlinir. Qeyd edilir ki, dekorativ bitki növlərinin böyük kolleksiyaları Mərkəzi Botanika Bağında və Bakıda yerləşən dendraridə araşdırılır. Bu kolleksiyada bəzi bitkilər potensial dekorativ xüsusiyyətlərə malikdir və bağlarda uğurla yetişdirilə bilər. Azərbaycanda bir çox bitkilər təbii yaşayış mühitinin itirilməsi, ziyadə toplama, yeni yollar, sənayenin inkişafi və s. kimi davam edən təhlükələr səbəbindən yox olmaq üzrədir. Təhlükə altında olan bu böyük növ müxtəlifliyinin yabanı təbiət üçün müstəsna əhəmiyyətini nəzərə alaraq onu artan təzyiqlərdən qorumaq üçün əsaslı səbəblər vardır.

Açar sözlor: dekorativ bitkilar, yabanı növlar, manşa, yaylma, introduksiya, Qafqaz 


\section{Флора Азербайджана для мирового садоводства}

Валида М. Али-заде

Институт Ботаники НАНА, Бадамдар 40, Баку, AZ1004, Азербайджан

Татьяна Шулькина

Полевой музей естествознания, 1400 S. Lake Shore Drive, Чикаго, Иллинойс 60605, США

Кавказ - это первая и единственная область в бывшем Советском Союзе, определенная как «горяч точка биоразнообразия» среди 25 других районов мира. Недавняя публикация новой географической карты подтвердила,что Кавказ - часть Европы. Среди стран Южного Кавказа Азербайджан - страна, обладающая наибольшим ботаническим богатством и чрезвычайно разнообразной природной флорой - прекрасный источник для нужд садоводства, который обеспечивается каждым из видов растительности ценными декоративными растениями. В статье приводится перечень важных декоративных растений, которые открывают превосходные возможности для интродукционной деятельности в различных условиях окружающей среды и крат- кий анализ их происхождения и распространения в Азербайджане. Деревья, кустарники и травянистые виды, произрастающие в регионах Азербайджана, многие из которых являются перспективными для озеленения, неизвестны или малоизвестны в садоводстве. Подчеркивается, что эндемичные травыТалыша представляют значительный интерес для садоводства из-за их крайне привлекательной природы. Некоторые виды чрезвычайно редки в природе и в посадках. Отмечается, что большие коллекции видов декоративных растений исследуются в Центральном ботаническом саду и дендрарии в Баку. Некоторые растения из этой коллекции являются перспективными декоративными растениями и могут успешно выращиваться в садах. Азербайджан является страной, где многие виды исчезают изза постоянных опасностей, таких как потеря среды обитания, чрезмерный сбор, новые дороги и промышленное развитие и т. д. Это весомые причины для охраны этого огромного разнообразия видов от растущих давлений, учитывая их исключительную важность для исчезающей дикой природы.

Ключевые слова: декоративные растения, дикие виды, происхождение, распространение, интродукциия, Кавказ 